\title{
Tumor Necrosis Factor Alpha Signaling and Organogenesis
}

\author{
Kai You ${ }^{1}$, Hui Gu${ }^{2}$, Zhengwei Yuan ${ }^{2}$ and Xuewen $X u^{2,3 *}$ \\ ${ }^{1}$ Department of Pediatrics, Shengjing Hospital of China Medical University, Shenyang, China, ${ }^{2}$ Key Laboratory of Health \\ Ministry for Congenital Malformation, Shengjing Hospital of China Medical University, Shenyang, China, ${ }^{3}$ Department \\ of Urology, Shengjing Hospital of China Medical University, Shenyang, China
}

Tumor necrosis factor alpha (TNF- $\alpha)$ plays important roles in processes such as immunomodulation, fever, inflammatory response, inhibition of tumor formation, and inhibition of viral replication. TNF- $\alpha$ and its receptors are ubiquitously expressed in developing organs and they regulate the survival, proliferation, and apoptosis of embryonic stem cells (ESCs) and progenitor cells. TNF- $\alpha$ is an important inflammatory factor that also regulates the inflammatory response during organogenesis, and its cytotoxic effects can interfere with normal developmental processes, even leading to the onset of diseases. This review summarizes the various roles of TNF- $\alpha$ in organogenesis in terms of its secreting pattern, concentration-dependent activities, and interactions with other signaling pathways. We also explored new potential functions of TNF- $\alpha$.

OPEN ACCESS

Edited by:

Yoshiko Takahashi, Kyoto University, Japan

Reviewed by:

Yasutaka Okabe,

Osaka University, Japan Hiroyasu Kidoya

Osaka University, Japan

${ }^{*}$ Correspondence:

Xuewen Xu

xuxw@sj-hospital.org

Specialty section:

This article was submitted to Morphogenesis and Patterning,

a section of the journal

Frontiers in Cell and Developmental

Biology

Received: 18 June 2021 Accepted: 08 July 2021

Published: 30 July 2021

Citation:

You K, Gu H, Yuan Z and Xu X (2021) Tumor Necrosis Factor Alpha Signaling and Organogenesis. Front. Cell Dev. Biol. 9:727075. doi: 10.3389/fcell.2021.727075
Keywords: tumor necrosis factor alpha, cell communication, development, morphogenesis, organogenesis

\section{INTRODUCTION}

Tumor necrosis factor alpha (TNF- $\alpha$ ) belongs to the TNF superfamily (Aggarwal, 2003) of proteins with highly similar structures and conserved interaction profiles (Bodmer et al., 2002). A macrophage cytotoxic factor was originally discovered during 1975 that could kill mouse fibrosarcoma L-929 cells and was thus termed "tumor necrosis factor" (Carswell et al., 1975). TNF- $\alpha$ plays important roles in various biological processes, such as immunomodulation, fever, inflammatory response, inhibition of tumor formation, and inhibition of virus replication (Bradley, 2019). TNF- $\alpha$ is encoded by a 3-kb gene located on chromosome $6 \mathrm{p} 21.3$ and it comprises four exons (Old, 1985). The precursor of TNF- $\alpha$ (pro-TNF- $\alpha$ ) is a type II transmembrane protein with a molecular weight of $26 \mathrm{kDa}$, consisting of mature TNF- $\alpha$ and a leader sequence, which contains a cytoplasmic domain, a transmembrane domain, and an extracellular domain. Synthesized proTNF is incorporated into the cell membrane and rapidly forms a homotrimer, which is then proteolytically cleaved by a multidomain metalloproteinase called TNF- $\alpha$ converting enzyme to release 17-kDa soluble (mature) TNF- $\alpha$ (Tang et al., 1996). Despite being a precursor, pro-TNF also exhibits biological activities; for instance, the homolog of pro-TNF, Eiger, induces apoptosis in compound eyes of Drosophila by activating the c-Jun $\mathrm{N}$-terminal kinases (JNKs) signaling pathway (Igaki et al., 2002), and concentric cardiac hypertrophy occurs in transgenic mice with up-regulated pro-TNF expression (Dibbs et al., 2003). The binding of TNF- $\alpha$ to its receptors activates three types of intracellular signaling pathways, including the NF-к B-, MAPK- JNK-, and caspase-8-mediated pathways, to promote various biological functions, such as the inflammatory response, as well as

Abbreviations: ESC, embryonic stem cell; VIC, valve interstitial cell; NPC, neural progenitor cell; BMSC, bone marrowderived mesenchymal stem cell; BMP, bone morphogenetic protein. 
cell survival, proliferation, differentiation, and apoptosis (Adrain et al., 2012). The physiological roles of TNF- $\alpha$ in developmental processes have recently gained attention. TNF- $\alpha$ promotes the growth of intestinal epithelium in fetuses by stimulating the development of intestinal stem cells (Schreurs et al., 2019). TNF$\alpha$ also promotes the apoptosis of cardiac valve interstitial cells (VICs). TNF- $\alpha$-knockout mice developed VIC hypertrophy at 16 days post-partum, indicating that TNF- $\alpha$ plays an important role in the development of cardiac valves (Wang et al., 2017).

This review summarizes the roles of $\mathrm{TNF}-\alpha$ in the development of various organs and associated diseases. We also highlight the mechanisms of TNF- $\alpha$ from multiple aspects, including its effects on stem cells/progenitor cells, secreted forms, concentration-dependent activities, and interactions with other signaling pathways.

\section{ROLES, ACTIONS, AND EFFECTS OF TNF- $\alpha$}

\section{TNF- $\alpha$ Participates in the Regulation of Organogenesis}

The effects of TNF- $\alpha$ can be traced back to gastrulation, during which it promotes embryonic differentiation and cell apoptosis (Sanders et al., 1997). Organogenesis is precisely regulated by a complex signaling network (Durdu et al., 2014), in which TNF- $\alpha$ is involved in regulating the development of multiple organs (Figure 1). TNF- $\alpha$ plays a central role in the process of neurogenesis in embryos and neonates by regulating the survival, proliferation, and differentiation of neural progenitor cells (NPCs) (Bernardino et al., 2008; Lan et al., 2012). TNF- $\alpha$ participates in various stages of brain development, by increasing the numbers of neurons in the early stage of embryonic development through activating the NF$\kappa \mathrm{B}$ signaling pathway, and induces neuronal apoptosis in the late stage of embryonic development by activating the caspase pathway (Figure 1A; Doherty, 2007). TNF- $\alpha$ promotes the differentiation of keratinocytes in neonates by increasing the rate of cornified envelope formation. It also promotes progression of the hair follicle cycle from the growth (anagen) to the regression (catagen) phase, thus playing important regulatory roles in epidermal development and hair follicle morphogenesis (Pillai et al., 1989; Tong and Coulombe, 2006). TNF- $\alpha$ promotes the proliferation of bone marrow-derived mesenchymal stem cells (BMSCs), osteoclast progenitor cells, and chondrocytes (Enomoto et al., 1990; Van Der Pluijm et al., 1991; Fang et al., 2019). TNF- $\alpha$ also promotes the migration of BMSCs without relying on the NF-кB signaling pathway (Sullivan et al., 2014). TNF- $\alpha$ activates the p38 MAPK signaling pathway in osteoblasts and chondrocytes to enhance bone resorption, thus promoting bone growth (Figure 1B; Tashjian et al., 1987; Kumar et al., 2001). TNF- $\alpha$ seemingly exhibits various effects across different developmental stages; for instance, it inhibits (Gilbert et al., 2000) and promotes (Sidney et al., 2014) the differentiation of osteoblasts in fetal and neonatal rats, respectively. TNF- $\alpha$ secreted by valvular endothelial cells in embryonic mice induces the apoptosis of VICs, whereby TNF$\alpha$-knockout mice have thickened heart valves (Wang et al., 2017). Chick embryo chorioallantoic membrane assays have shown that TNF- $\alpha$ promotes angiogenesis (Figure 1C; Olivo et al., 1992; Fang et al., 2019). The embryos of TNF- $\alpha$-knockout mice are more prone to developing limb deformities after exposure to cyclophosphamide, confirming that TNF- $\alpha$ functions as a cytokine that protects embryos against teratogens (Torchinsky et al., 2003). TNF- $\alpha$ promotes the growth of intestinal stem cells in the human fetus (Figure 1D; Schreurs et al., 2019). The onset of severe hepatic dysplasia in embryos of TNF$\alpha$-knockout zebrafish showed that TNF- $\alpha$ plays an important role in liver development (Qi et al., 2010). TNF- $\alpha$ secreted by tracheal cartilage regulates the differentiation of airway epithelial cells in embryos (Figure 1E; Turcatel et al., 2017). Besides, mechanical ventilation can lead to bronchopulmonary dysplasia in TNF$\alpha$-knockout mice by inducing the transforming growth factor (TGF) signaling pathway, indicating that the balance between TNF- $\alpha$ and TGF signaling is essential for airway development (Ehrhardt et al., 2016). Therefore, TNF- $\alpha$ participates in the regulation of cell survival and proliferation by activation of NF$\kappa \mathrm{B}$ signaling, cell differentiation and proliferation by activation of MAPK signaling, and apoptosis by activation of caspase- 8 signaling, so that it plays important roles in the development of various organs. Further studies are required to gain insights into the regulatory mechanism of TNF- $\alpha$ in organ development and cellular signaling pathways.

\section{Effects of TNF- $\alpha$ on Stem Cells/Progenitors}

Tumor necrosis factor alpha might exert different effects on embryonic stem cells (ESCs), progenitor cells, and differentiated cells. It not only inhibits the self-renewal of mouse ESCs but also induces their apoptosis and inhibits their differentiation into embryos (Figure 2A; Wuu et al., 1998). TNF- $\alpha$ promotes the migration of ESCs by binding to TNF receptor 2 to activate p38 and JNKs in vivo and in vitro (Chen et al., 2003).

Tumor necrosis factor alpha is also involved in regulating the proliferation, apoptosis, and differentiation of progenitor cells. It promotes the proliferation and differentiation of neuroblasts into astrocytes in the human fetal cortex (Peng et al., 2008; Lan et al., 2012), inhibits the differentiation of cortical oligodendrocyte precursor cells and induces their apoptosis in neonatal rats (Su et al., 2011; Bernardo et al., 2017). TNF- $\alpha$ promotes the differentiation of NPCs in the subventricular zone of neonatal mice. Moreover, low and high concentrations of TNF$\alpha$, respectively, promote the proliferation and apoptosis of NPCs (Bernardino et al., 2008). TNF- $\alpha$ promotes the survival of human embryonic NPCs by activating NF- $\mathrm{B}$ signaling pathway (Kim et al., 2018). TNF- $\alpha$ inhibits the proliferation of hippocampal precursor cells in mice (Wang et al., 2018) and the differentiation of NPCs into neurons in embryos (Liu et al., 2005), and promotes the proliferation of osteoclast progenitor cells in embryonic mice (Van Der Pluijm et al., 1991). TNF- $\alpha$ plays an important regulatory role in the differentiation of fetal thymic and lymphoid precursor cells (Zúñiga-Pflücker et al., 1995). TNF- $\alpha$ also inhibits 


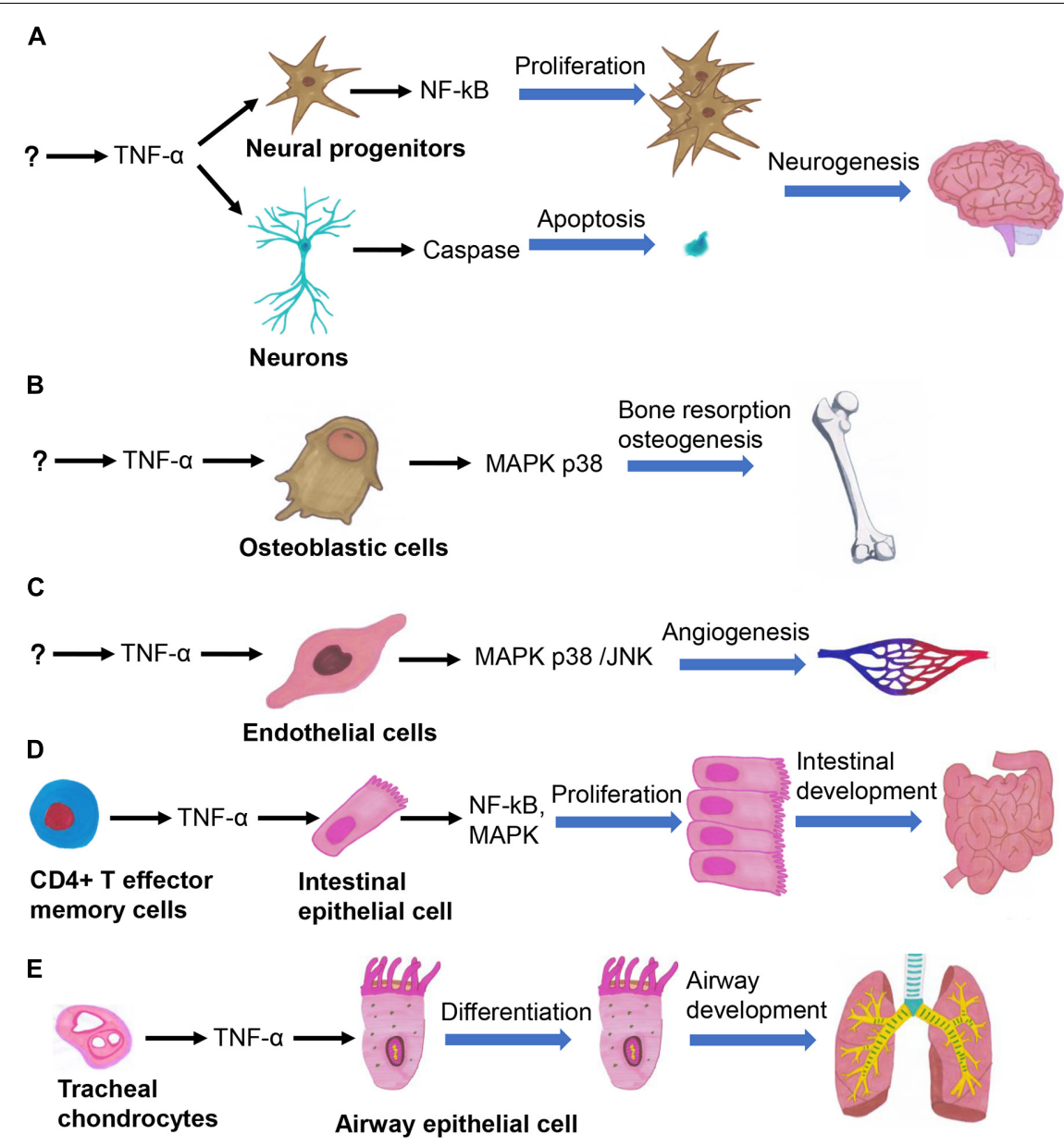

FIGURE 1 | TNF- $\alpha$ regulates several important biological processes in organogenesis, such as the neurogenesis (A), osteogenesis (B), angiogenesis (C), intestinal development (D), and airway development (E).

the differentiation of Schwann cells in neonatal rats, osteoblasts in fetal rats, and colonic epithelial cells in human fetuses (Gilbert et al., 2000, 2002; Lisak et al., 2001; Hýžialová et al., 2008), and induces the apoptosis of oocytes in neonatal rats (Morrison and Marcinkiewicz, 2002). Therefore, TNF- $\alpha$ tends to promote proliferation and inhibit differentiation of the progenitors by activating NF- $\kappa \mathrm{B}$ signaling, while with regards to stem cells and differentiated cells, TNF- $\alpha$ tends to induce their apoptosis.

\section{Secreted Forms and Biological Functions of TNF- $\alpha$}

Although transmembrane TNF- $\alpha$ (pro-TNF) is biologically active, TNF- $\alpha$ primarily exerts autocrine and paracrine functions in a soluble, trimeric form during developmental processes. TNF$\alpha$ acts as an autocrine and paracrine growth factor that stimulates the proliferation of hematopoietic cells and B cells (Figure 2B; Boussiotis et al., 1994). Autocrine TNF- $\alpha$ signaling is required for macrophage maturation (Witsell and Schook, 1992; Boyle et al., 2003; Chen et al., 2004). Autocrine TNF- $\alpha$ signaling promotes the survival and differentiation of monocytes into dendritic cells (Lehner et al., 2012). Autocrine TNF- $\alpha$ signaling is also involved in the regulation of growth, differentiation, and maturation of lymphokine-activated killer T cells (Innins et al., 1992). TNF- $\alpha$ regulates the differentiation of osteoclasts and bone resorption (Tani-Ishii et al., 1999; Zou et al., 2001), and promotes myoblasts differentiation through an autocrine process (Li and Schwartz, 2001). TNF- $\alpha$ activates and promotes astrocyte proliferation through a paracrine process (Rodgers et al., 2020).

\section{Concentration-Dependent Effects of TNF- $\alpha$}

Low concentrations of TNF- $\alpha$ tend to promote cell proliferation, whereas high concentrations tend to inhibit cell proliferation and even induce the apoptosis of neural stem cells/progenitor cells in the subventricular zone of neonatal mice, and of osteoclast progenitor cells and intestinal stem cells in fetal mice (Figure 2C; Van Der Pluijm et al., 1991; Bernardino et al., 2008; Schreurs et al., 2019). The biological effects of TNF- $\alpha$ are enhanced in a concentration-dependent manner. For example, higher concentrations of TNF- $\alpha$ inhibit the proliferation of ESCs in mice (Wuu et al., 1998), promote NPC proliferation in the human fetal cortex (Peng et al., 2008), induce the apoptosis of dopaminergic 


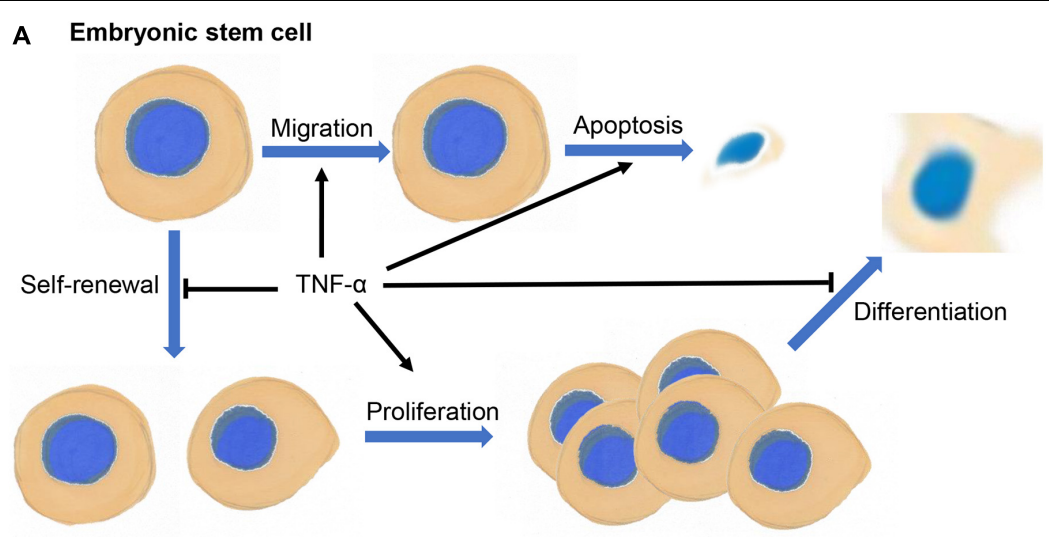

B Paracrine secretion

\section{Autocrine secretion}

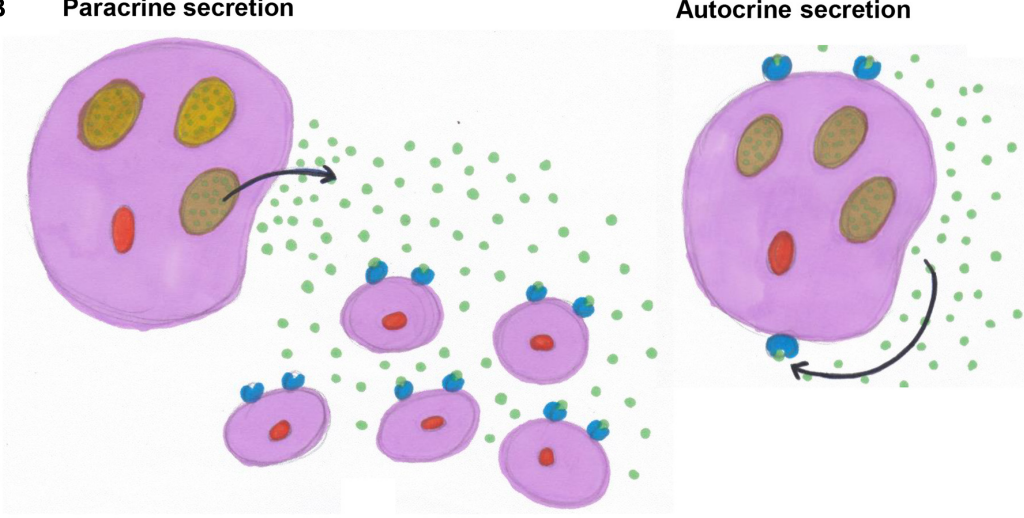

C

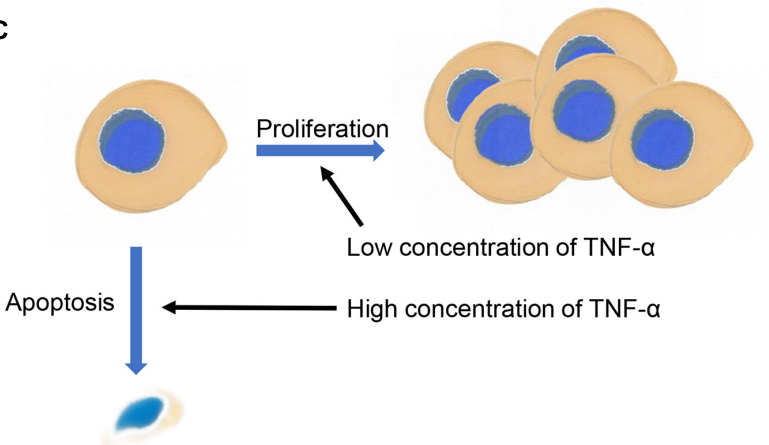

FIGURE 2 | (A) TNF- $\alpha$ inhibits the self-renewal of embryonic stem cells and promotes their migration, and inhibits the differentiation of progenitor cells and promotes their proliferation and survival. (B) TNF- $\alpha$ acts on its secreting cells (autocrine signaling) or surrounding cells (paracrine signaling). (C) TNF- $\alpha$ promotes cell proliferation at low concentrations and inhibit cell proliferation and induce apoptosis at high concentrations.

neurons in embryonic mice and chondrocytes in chicken embryos (Aizawa et al., 2001; McGuire et al., 2001; Doherty, 2007), inhibit osteogenic differentiation of BMSCs in rats (Gilbert et al., 2000, 2002; Fang et al., 2019), and promote lung branching morphogenesis and expression surfactant proteins in embryonic mice (Jaskoll et al., 1994).

\section{Crosstalk Between TNF- $\alpha$ and Other Signaling Pathways}

Tumor necrosis factor alpha interacts extensively with fibroblast growth factor (FGF) family, Wnt family, and TGF- $\beta$ superfamily members to co-regulate developmental processes. It promotes angiogenesis by inducing basic FGF and FGF-1 expression in endothelial cells (Figure 3A; Maier et al., 1996; Yoshida et al., 1997).

Tumor necrosis factor alpha inhibition promotes the functional recovery of nerves by activating the Wnt3a signaling pathway in BMSCs (Peng et al., 2017). TNF- $\alpha$ inhibits adipogenesis by activating the Wnt signaling pathway in pre-adipocytes, suggesting that it is involved in determining the fate of adipocytes (Qadir et al., 2011). TNF- $\alpha$ also suppresses bone formation by inhibiting the Wnt signaling in osteoblasts (Jaskoll et al., 1994; Qin et al., 2015; Chen et al., 2020; 


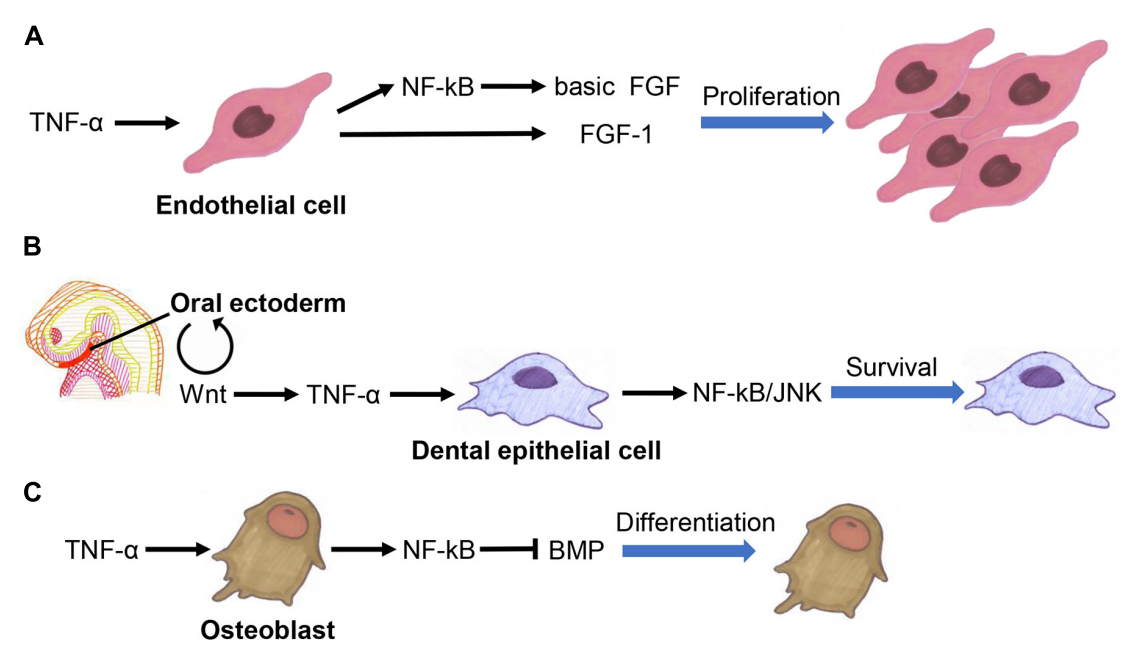

FIGURE 3 | Crosstalk between TNF- $\alpha$ fibroblast growth factor (FGF) family (A), Wnt family (B), and TGF- $\beta$ superfamily members (C) in the regulation of organogenesis.

Li et al., 2020). The Wnt signaling pathway is involved in the activation of TNF- $\alpha$ signaling to ensure the survival of dental epithelial cells in early tooth development (Figure 3B; Laurikkala et al., 2001).

Tumor necrosis factor alpha regulates the differentiation of osteoblasts by affecting the bone morphogenetic proteins (BMP) signaling pathway (Figure 3C; Singhatanadgit et al., 2006; Mukai et al., 2007; Yamazaki et al., 2009; Matsumoto et al., 2010). It also promotes tooth development by upregulating the expression of BMP-2 and BMP-3 in dental follicles (Yao et al., 2010). Besides, BMP signaling can promote bone development by inhibiting the TNF- $\alpha$-mediated apoptosis of osteoblasts (Chen et al., 2001). TNF- $\alpha$ induces activin A expression in BMSCs, eosinophils, lymphatic endothelial cells, and amniotic cells (Takahashi et al., 1992; Abe et al., 2013; Kelly et al., 2016; Yoshimatsu et al., 2020).

Tumor necrosis factor alpha induces the expression of hepatocyte growth factor in human bone marrow- or adiposederived progenitor cells and in MSCs to promote tissue growth and repair (Wang et al., 2006; Zhang et al., 2010). TNF- $\alpha$ has also been demonstrated to promote angiogenesis by inducing the expression of ephrin A1 and erythropoietin in endothelial cells (Cheng and Chen, 2001; Wang et al., 2011). Erythropoietin can promote the proliferation and inhibit the differentiation of erythroid cells and hematopoietic stem cells by inducing the biosynthesis and secretion of TNF- $\alpha$ (Jacobs-Helber et al., 2003; Chen et al., 2004). Notch-activated TNF- $\alpha$ signaling in endothelial cells helps to prevent heart valve thickening by promoting VIC apoptosis (Wang et al., 2017).

\section{Inflammatory Response Triggers Abnormal Organogenesis by Activating the TNF- $\alpha$}

The cytotoxic effects of TNF- $\alpha$ during inflammation might lead to abnormal organogenesis. Previous studies have confirmed that TNF- $\alpha$ exerts neurotoxic effects in vivo and in vitro and negatively affects brain development in vivo (Chao and $\mathrm{Hu}$, 1994; Peng et al., 2008; Seleme et al., 2017). Microglia activated during inflammation can inhibit the axon growth of neurons and induce neuronal apoptosis via TNF- $\alpha$ in neonatal rats (Bogdan et al., 1997; Cacci et al., 2005; Nimmervoll et al., 2013; Nolan et al., 2014; Cheng et al., 2016). TNF- $\alpha$ is involved in the onset of hydrocephalus, and its expression in astrocytes is associated with the severity of hydrocephalus in animal models (Jiménez et al., 2014). The induction of TNF- $\alpha$ expression in embryonic mice by cyclophosphamide (a teratogen) can lead to craniofacial malformations (Ivnitsky et al., 1998). Moreover, the finding that TNF- $\alpha$ inhibits neuronal dendritic growth in the cortex of embryonic mice might indicate increased risk of mental illness in humans (Gilmore et al., 2004; Babri et al., 2014). A high-fat diet in female rats can lead to the elevation of hepatic TNF- $\alpha$ to a level that can cause liver damage in their newborn infants (Kačarević et al., 2017). TNF- $\alpha$ promotes the maturation of pancreatic dendritic cells and activates pancreatic $\mathrm{T}$ cells in neonatal mice, causing damage to islet $\beta$ cells and triggering the onset of type I diabetes (Lee et al., 2005). TNF- $\alpha$ might cause metatarsal growth disorder in fetal rats, suggesting that chronic inflammatory diseases can cause developmental disorders of bone in children by upregulating TNF- $\alpha$ expression (Mårtensson et al., 2004). Elevated hepatic and placental levels of TNF- $\alpha$ in female mice due to intrauterine infections might lead to delayed fetal bone development (Xu et al., 2006). TNF$\alpha$ can increase the methylation levels of myoD CpG island in proliferating myoblasts, resulting in a reduced number of skeletal muscle cells (Sharples et al., 2016). TNF- $\alpha$ causes damage to the intestinal mucosa of neonatal rats by triggering the death of intestinal epithelial cells, and the subsequent onset of necrotizing enterocolitis (Halpern et al., 2006; Tayman et al., 2016; Schreurs et al., 2019). Elevated TNF- $\alpha$ in amniotic fluid can lead to the apoptosis of alveolar epithelial cells, localized atelectasis, alveolar inflammation, and premature birth (Sadowsky et al., 2006). All considered, abnormal factors such as inflammation in 
developmental processes might increase localized levels of TNF$\alpha$, and exerts cytotoxic effects that can disrupt organogenesis and trigger the onset of associated diseases.

\section{DISCUSSION}

This review summarized the progress in understanding the effects of TNF- $\alpha$ on organogenesis. TNF- $\alpha$ is a multifunctional cytokine that regulates important biological processes in organogenesis, such as the proliferation, differentiation, and apoptosis of neurons, osteoblasts, endothelial cells, hematopoietic progenitor cells, intestinal epithelial cells, and airway epithelial cells. TNF$\alpha$ mainly inhibits the self-renewal of ESCs and promotes their migration, and inhibits the differentiation of progenitor cells and promotes their proliferation and survival. During organogenesis, TNF- $\alpha$ mainly acts on its secreting cells (autocrine signaling) or surrounding cells (paracrine signaling). TNF- $\alpha$ tends to promote cell proliferation at low concentrations and inhibit cell proliferation and induce apoptosis at high concentrations. TNF$\alpha$ interacts extensively with the FGF, Wnt, and TGF- $\beta$ signaling pathways to co-regulate organogenesis. It is also an important inflammatory factor that regulates the inflammatory response and exerts cytotoxic effects. The overwhelming cytotoxic effect of TNF- $\alpha$ during organogenesis due to inflammation interferes with normal developmental processes and can trigger disease onset. Despite considerable knowledge about TNF- $\alpha$ and its functions in organogenesis, several questions remain. For example,

\section{REFERENCES}

Abe, Y., Komatsubara, M., Saito, M., Toda, M., Shinozaki, H., Tamura, T., et al. (2013). Activin A is stimulated by tumor necrosis factor-alpha and modulates collagen gene expression in human amniotic cells. J. Endocrinol. Invest. 36, 515-520.

Adrain, C., Zettl, M., Christova, Y., Taylor, N., and Freeman, M. (2012). Tumor necrosis factor signaling requires iRhom 2 to promote trafficking and activation of TACE. Science 335, 225-228. doi: 10.1126/science.1214400

Aggarwal, B. B. (2003). Signalling pathways of the TNF superfamily: a doubleedged sword. Nat. Rev. Immunol. 3, 745-756. doi: 10.1038/nri1184

Aizawa, T., Kon, T., Einhorn, T. A., and Gerstenfeld, L. C. (2001). Induction of apoptosis in chondrocytes by tumor necrosis factor-alpha. J. Orthop. Res. 19, 785-796. doi: 10.1016/s0736-0266(00)00078-4

Babri, S., Doosti, M. H., and Salari, A. A. (2014). Tumor necrosis factor-alpha during neonatal brain development affects anxiety- and depression-related behaviors in adult male and female mice. Behav. Brain Res. 261, 305-314. doi: 10.1016/j.bbr.2013.12.037

Bernardino, L., Agasse, F., Silva, B., Ferreira, R., Grade, S., and Malva, J. O. (2008). Tumor necrosis factor- $\alpha$ modulates survival, proliferation, and neuronal differentiation in neonatal subventricular zone cell cultures. Stem Cells 26, 2361-2371. doi: 10.1634/stemcells.2007-0914

Bernardo, A., Giammarco, M. L., De Nuccio, C., Ajmone-Cat, M. A., Visentin, S., De Simone, R., et al. (2017). Docosahexaenoic acid promotes oligodendrocyte differentiation via PPAR- $\gamma$ signalling and prevents tumor necrosis factor- $\alpha-$ dependent maturational arrest. Biochim. Biophys. Acta 1862, 1013-1023. doi: 10.1016/j.bbalip.2017.06.014

Bodmer, J. L., Schneider, P., and Tschopp, J. (2002). The molecular architecture of the TNF superfamily. Trends Biochem. Sci. 27, 19-26.

Bogdan, I., Leib, S. L., Bergeron, M., Chow, L., and Täuber, M. G. (1997). Tumor necrosis factor- $\alpha$ contributes to apoptosis in hippocampal neurons during how TNF- $\alpha$ prevents the activation of undesirable immune responses during developmental processes remains obscure. Low concentrations of TNF- $\alpha$ promote the development of intestinal epithelium without triggering inflammatory response (Schreurs et al., 2019), but whether a more fine-tuned regulatory mechanism exists remains unclear. Furthermore, the regulatory mechanism underlying various effects of TNF- $\alpha$ (such as promoting proliferation, differentiation, and apoptosis) on the same type of cells remains unclear. Details of the regulatory mechanisms of TNF- $\alpha$ during organogenesis requires further investigation.

\section{AUTHOR CONTRIBUTIONS}

KY was in charge of acquisition of reference articles and critical revision of the manuscript for important intellectual content. HG and $\mathrm{ZY}$ were in charge of critical revision of the manuscript for important intellectual content. XX was in charge of drafting of the manuscript and supervision. All authors contributed to the article and approved the submitted version.

\section{ACKNOWLEDGMENTS}

The authors acknowledge Renge Bu (Department of Urology, Shengjing Hospital of China Medical University, Shenyang, China), for his administrative, technical, or material support.

experimental group B streptococcal meningitis. J. Infect. Dis. 176, 693-697. doi: $10.1086 / 514092$

Boussiotis, V. A., Nadler, L. M., Strominger, J. L., and Goldfeld, A. E. (1994). Tumor necrosis factor $\alpha$ is an autocrine growth factor for normal human B cells. Proc. Natl. Acad. Sci. U.S A. 91, 7007-7011. doi: 10.1073/pnas.91.15. 7007

Boyle, J. J., Weissberg, P. L., and Bennett, M. R. (2003). Tumor necrosis factor- $\alpha$ promotes macrophage-induced vascular smooth muscle cell apoptosis by direct and autocrine mechanisms. Arterioscler. Thromb. Vasc. Biol. 23, 1553-1558. doi: 10.1161/01.atv.0000086961.44581.b7

Bradley, C. A. (2019). Prophylactic TNF blockade reduces autoimmune toxicity. Nat. Rev. Drug Discov. 18:500. doi: 10.1038/d41573-019-00093-w

Cacci, E., Claasen, J. H., and Kokaia, Z. (2005). Microglia-derived tumor necrosis factor- $\alpha$ exaggerates death of newborn hippocampal progenitor cells in vitro. J. Neurosci. Res. 80, 789-797. doi: 10.1002/jnr.20531

Carswell, E. A., Old, L. J., Kassel, R. L., Green, S., Fiore, N., and Williamson, B. (1975). An endotoxin induced serum factor that cuases necrosis of tumors. Proc. Natl. Acad. Sci. U.S.A. 72, 3666-3670. doi: 10.1073/pnas.72.9. 3666

Chao, C. C., and Hu, S. (1994). Tumor necrosis factor-alpha potentiates glutamate neurotoxicity in human fetal brain cell cultures. Dev. Neurosci. 16, 172-179. doi: $10.1159 / 000112104$

Chen, J., Jacobs-Helber, S. M., Barber, D. L., and Sawyer, S. T. (2004). Erythropoietin-dependent autocrine secretion of tumor necrosis factor-alpha in hematopoietic cells modulates proliferation via MAP kinase-ERK-1/2 and does not require tyrosine docking sites in the EPO receptor. Exp. Cell Res. 298, 155-166. doi: 10.1016/j.yexcr.2004.04.009

Chen, L., Bao, J., Yang, Y., Wang, Z., Xia, M., Tan, J., et al. (2020). Autophagy was involved in tumor necrosis factor- $\alpha$-inhibited osteogenic differentiation of murine calvarial osteoblasts through $\mathrm{Wnt} / \beta$-catenin pathway. Tissue Cell. 67:101401. doi: 10.1016/j.tice.2020.101401 
Chen, S., Guttridge, D. C., Tang, E., Shi, S., Guan, K. L., and Wang, C. Y. (2001). Suppression of tumor necrosis factor-mediated apoptosis by nuclear factor $\mathrm{\kappa B}$ independent bone morphogenetic protein/smad signaling. J. Biol. Chem. 276, 39259-39263. doi: 10.1074/jbc.m105335200

Chen, Y., Ke, Q., Yang, Y., Rana, J. S., Tang, J., Morgan, J. P., et al. (2003). Cardiomyocytes overexpressing TNF- $\alpha$ attract migration of embryonic stem cells via activation of p38 and c-Jun amino-terminal kinase. FASEB J. 17, 2231-2239. doi: 10.1096/fj.03-0030com

Cheng, H., Davis, D. A., Hasheminassab, S., Sioutas, C., Morgan, T. E., and Finch, C. E. (2016). Urban traffic-derived nanoparticulate matter reduces neurite outgrowth via TNF $\alpha$ in vitro. J. Neuroinflammation 13:19. doi: 10.1186/s12974016-0480-3

Cheng, N., and Chen, J. (2001). Tumor necrosis factor- $\alpha$ induction of endothelial ephrin A1 expression is mediated by a p38 MAPK- and SAPK/JNK-dependent but nuclear factor-кB-independent mechanism. J. Biol. Chem. 276, 1377113777. doi: 10.1074/jbc.m009147200

Dibbs, Z. I., Diwan, A., Nemoto, S., DeFreitas, G., Abdellatif, M., Carabello, B. A., et al. (2003). Targeted overexpression of transmembrane tumor necrosis factor provokes a concentric cardiac hypertrophic phenotype. Circulation 108, 1002-1008. doi: 10.1161/01.cir.0000085203.46621.f4

Doherty, G. H. (2007). Developmental switch in the effects of TNF $\alpha$ on ventral midbrain dopaminergic neurons. Neurosci. Res. 57, 296-305. doi: 10.1016/j. neures.2006.10.019

Durdu, S., Iskar, M., Revenu, C., Schieber, N., Kunze, A., Bork, P., et al. (2014). Luminal signalling links cell communication to tissue architecture during organogenesis. Nature 515, 120-124. doi: 10.1038/nature13852

Ehrhardt, H., Pritzke, T., Oak, P., Kossert, M., Biebach, L., Förster, K., et al. (2016). Absence of TNF- $\alpha$ enhances inflammatory response in the newborn lung undergoing mechanical ventilation. Am. J. Physiol. Lung Cell. Mol. Physiol. 310, L909-L918.

Enomoto, M., Pan, H. O., Kinoshita, A., Yutani, Y., Suzuki, F., and Takigawa, M. (1990). Effects of tumor necrosis factor $\alpha$ on proliferation and expression of differentiated phenotypes in rabbit costal chondrocytes in culture. Calcif. Tissue Int. 47, 145-151. doi: 10.1007/bf02555979

Fang, B., Wang, D., Zheng, J., Wei, Q., Zhan, D., Liu, Y., et al. (2019). Involvement of tumor necrosis factor alpha in steroid-associated osteonecrosis of the femoral head: friend or foe? Stem Cell Res. Ther. 10:5. doi: 10.1186/s13287-018-1112-x

Gilbert, L., He, X., Farmer, P., Boden, S., Kozlowski, M., Rubin, J., et al. (2000). Inhibition of osteoblast differentiation by tumor necrosis factor- $\alpha$. Endocrinology 141, 3956-3964. doi: 10.1210/endo.141.11.7739

Gilbert, L., He, X., Farmer, P., Rubin, J., Drissi, H., Van Wijnen, A. J., et al. (2002). Expression of the osteoblast differentiation factor RUNX2 (Cbfa1/AML3/Pebp2 $\alpha \mathrm{A}$ ) is inhibited by tumor necrosis factor- $\alpha$. J. Biol. Chem. 277, 2695-2701. doi: 10.1074/jbc.m106339200

Gilmore, J. H., Jarskog, L. F., Vadlamudi, S., and Lauder, J. M. (2004). Prenatal infection and risk for schizophrenia: IL-1 $\beta$, IL-6, and TNF $\alpha$ inhibit cortical neuron dendrite development. Neuropsychopharmacology 29, 1221-1229. doi: 10.1038/sj.npp.1300446

Halpern, M. D., Clark, J. A., Saunders, T. A., Doelle, S. M., Hosseini, D. M., Stagner, A. M., et al. (2006). Reduction of experimental necrotizing enterocolitis with anti-TNF- $\alpha$. Am. J. Physiol. Gastrointest. Liver Physiol. 290, G757-G764. doi: 10.1152/ajpgi.00408.2005

Hýžǐalová, M., Hofmanová, J., Pacherník, J., Vaculová, A., and Kozubík, A. (2008). The interaction of butyrate with TNF- $\alpha$ during differentiation and apoptosis of colon epithelial cells: role of NF-кB activation. Cytokine. 44, 33-43. doi: 10.1016/j.cyto.2008.06.003

Igaki, T., Kanda, H., Yamamoto-Goto, Y., Kanuka, H., Kuranaga, E., Aigaki, T., et al. (2002). Eiger, a TNF superfamily ligand that triggers the Drosophila JNK pathway. EMBO J. 21, 3009-3018. doi: 10.1093/emboj/cdf306

Innins, E. K., Gatanaga, M., Eden, M., Van Knudsen, K. L., Granger, G. A., and Gatanaga, T. (1992). The autocrine role of tumor necrosis factor in the proliferation and functional differentiation of human lymphokine-activated $\mathrm{T}$ killer cells (T-LAK) in vitro. Cytokine 4, 391-396. doi: 10.1016/1043-4666(92) 90083-4

Ivnitsky, I., Torchinsky, A., Gorivodsky, M., Zemliak, I., Orenstein, H., Savion, S., et al. (1998). TNF- $\alpha$ expression in embryos exposed to a teratogen. Am. J. Reprod. Immunol. 40, 431-440. doi: 10.1111/j.1600-0897.1998.tb00 430.x
Jacobs-Helber, S. M., Roh, K. H, Bailey, D., Dessypris, E. N., Ryan, J. J., Chen, J., et al. (2003). Tumor necrosis factor-alpha expressed constitutively in erythroid cells or induced by erythropoietin has negative and stimulatory roles in normal erythropoiesis and erythroleukemia. Blood 101, 524-531. doi: 10.1182/blood2001-11-0084

Jaskoll, T., Boyer, P. D., and Melnick, M. (1994). Tumor necrosis factor- $\alpha$ and embryonic mouse lung morphogenesis. Dev. Dyn. 201, 137-150. doi: 10.1002/ aja.1002010205

Jiménez, A. J., Rodríguez-Pérez, L. M., Domínguez-Pinos, M. D., Gómez-Roldán, M. C., García-Bonilla, M., Ho-Plagaro, A., et al. (2014). Increased levels of tumour necrosis factor alpha $(\mathrm{TNF} \alpha)$ but not transforming growth factor-beta 1 (TGF $\beta 1$ ) are associated with the severity of congenital hydrocephalus in the hyh mouse. Neuropathol. Appl. Neurobiol. 40, 911-932. doi: 10.1111/nan.12115 Kačarević, ŽP., Grgić, A., Šnajder, D., Bijelić, N., Belovari, T., Cvijanović, O., et al. (2017). Different combinations of maternal and postnatal diet are reflected in changes of hepatic parenchyma and hepatic TNF-alpha expression in male rat offspring. Acta Histochem. 119, 719-726. doi: 10.1016/j.acthis.2017.09.003

Kelly, E. A., Esnault, S., Johnson, S. H., Liu, L. Y., Malter, J. S., Burnham, M. E., et al. (2016). Human eosinophil activin A synthesis and mRNA stabilization are induced by the combination of IL-3 plus TNF. Immunol. Cell Biol. 94, 701-708. doi: $10.1038 /$ icb. 2016.30

Kim, M., Jung, K., Kim, I. S., Lee, I. S., Ko, Y., Shin, J. E., et al. (2018). TNF- $\alpha$ induces human neural progenitor cell survival after oxygen-glucose deprivation by activating the NF-кB pathway. Exp. Mol. Med. 50, 1-14. doi: 10.1038/ s12276-018-0033-1

Kumar, S., Votta, B. J., Rieman, D. J., Badger, A. M., Gowen, M., and Lee, J. C. (2001). IL-1- and TNF-induced bone resorption is mediated by p38 mitogen activated protein kinase. J. Cell. Physiol. 187, 294-303. doi: 10.1002/jcp.1082

Lan, X., Chen, Q., Wang, Y., Jia, B., Sun, L., Zheng, J., et al. (2012). TNF- $\alpha$ affects human cortical neural progenitor cell differentiation through the autocrine secretion of leukemia inhibitory factor. PLoS One 7:e50783. doi: 10.1371/ journal.pone.0050783

Laurikkala, J., Mikkola, M., Mustonen, T., Åberg, T., Koppinen, P., Pispa, J., et al. (2001). TNF signaling via the ligand-receptor pair ectodysplasin and edar controls the function of epithelial signaling centers and is regulated by Wnt and activin during tooth organogenesis. Dev. Biol. 229, 443-455. doi: 10.1006/dbio.2000.9955

Lee, L. F., Xu, B., Michie, S. A., Beilhack, G. F., Warganich, T., Turley, S., et al. (2005). The role of TNF- $\alpha$ in the pathogenesis of type 1 diabetes in the nonobese diabetic mouse: analysis of dendritic cell maturation. Proc. Natl. Acad. Sci. U.S.A. 102, 15995-16000. doi: 10.1073/pnas.0508122102

Lehner, M., Kellert, B., Proff, J., Schmid, M. A., Diessenbacher, P., Ensser, A., et al. (2012). Autocrine TNF is critical for the survival of human dendritic cells by regulating BAK, BCL-2, and FLIP L. J. Immunol. 188, 4810-4818. doi: 10.4049/jimmunol.1101610

Li, X., Ren, G., Cai, C., Yang, X., Nie, L., Jing, X., et al. (2020). TNF- $\alpha$ regulates the osteogenic differentiation of bone morphogenetic factor 9 adenovirustransduced rat follicle stem cells via Wnt signaling. Mol. Med. Rep. 22, 3141-3150.

Li, Y.-P., and Schwartz, R. J. (2001). TNF- $\alpha$ regulates early differentiation of C2C12 myoblasts in an autocrine fashion. FASEB J. 15, 1413-1415. doi: 10.1096/fj.000632fje

Lisak, R. P., Bealmear, B., Benjamins, J. A., and Skoff, A. M. (2001). Interferon- $\gamma$ tumor necrosis factor-and transforming growth factor- $\beta$ inhibit cyclic AMPinduced Schwann cell differentiation. Glia 36, 354-363. doi: 10.1002/glia. 1122

Liu, Y. P., Lin, H. I., and Tzeng, S. F. (2005). Tumor necrosis factor- $\alpha$ and interleukin-18 modulate neuronal cell fate in embryonic neural progenitor culture. Brain Res. 1054, 152-158. doi: 10.1016/j.brainres.2005.06.085

Maier, J. A., Morelli, D., Ménard, S., Colnaghi, M. I., and Balsari, A. (1996). Tumornecrosis-factor-induced fibroblast growth factor-1 acts as a survival factor in a transformed endothelial cell line. Am. J. Pathol. 149, 945-952.

Mårtensson, K., Chrysis, D., and Sävendahl, L. (2004). Interleukin-1 $\beta$ and TNF- $\alpha$ act in synergy to inhibit longitudinal growth in fetal rat metatarsal bones. J. Bone Miner. Res. 19, 1805-1812. doi: 10.1359/jbmr.040805

Matsumoto, Y., Otsuka, F., Takano, M., Mukai, T., Yamanaka, R., Takeda, M., et al. (2010). Estrogen and glucocorticoid regulate osteoblast differentiation through the interaction of bone morphogenetic protein- 2 and tumor necrosis factor- $\alpha$ 
in C2C12 cells. Mol. Cell. Endocrinol. 325, 118-127. doi: 10.1016/j.mce.2010. 05.004

McGuire, S. O., Ling, Z. D., Lipton, J. W., Sortwell, C. E., Collier, T. J., and Carvey, P. M. (2001). Tumor necrosis factor $\alpha$ is toxic to embryonic mesencephalic dopamine neurons. Exp. Neurol. 169, 219-230. doi: 10.1006/exnr.2001.7688

Morrison, L. J., and Marcinkiewicz, J. L. (2002). Tumor necrosis factor $\alpha$ enhances oocyte/follicle apoptosis in the neonatal rat ovary. Biol. Reprod. 66, 450-457. doi: 10.1095/biolreprod66.2.450

Mukai, T., Otsuka, F., Otani, H., Yamashita, M., Takasugi, K., Inagaki, K., et al. (2007). TNF- $\alpha$ inhibits BMP-induced osteoblast differentiation through activating SAPK/JNK signaling. Biochem. Biophys. Res. Commun. 356, 10041010. doi: 10.1016/j.bbrc.2007.03.099

Nimmervoll, B., White, R., Yang, J. W., An, S., Henn, C., Sun, J. J., et al. (2013). LPSinduced microglial secretion of TNF $\alpha$ increases activity-dependent neuronal apoptosis in the neonatal cerebral cortex. Cereb. Cortex 23, 1742-1755. doi: $10.1093 /$ cercor/bhs156

Nolan, A. M., Collins, L. M., Wyatt, S. L., Gutierrez, H., and O'Keeffe, G. W. (2014). The neurite growth inhibitory effects of soluble TNF $\alpha$ on developing sympathetic neurons are dependent on developmental age. Differentiation 88, 124-130. doi: 10.1016/j.diff.2014.12.006

Old, L. J. (1985). Tumor necrosis factor (TNF). Science 230, 630-632.

Olivo, M., Bhardwaj, R., Schulze-Osthoff, K., Sorg, C., Jacob, H. J., and Flamme, I. (1992). A comparative study on the effects of tumor necrosis factor- $\alpha$ (TNF- $\alpha$ ), human angiogenic factor (h-AF) and basic fibroblast growth factor (bFGF) on the chorioallantoic membrane of the chick embryo. Anat. Rec. 234, 105-115. doi: 10.1002/ar.1092340112

Peng, H., Whitney, N., Wu, Y., Tian, C., Dou, H., Zhou, Y., et al. (2008). HIV-1infected and/or immune-activated macrophage-secreted TNF- $\alpha$ affects human fetal cortical neural progenitor cell proliferation and differentiation. Glia 56, 903-916. doi: 10.1002/glia.20665

Peng, R. J., Jiang, B., Ding, X. P., Huang, H., Liao, Y. W., Peng, G., et al. (2017). Effect of TNF- $\alpha$ inhibition on bone marrow-derived mesenchymal stem cells in neurological function recovery after spinal cord injury via the Wnt signaling pathway in a rat model. Cell. Physiol. Biochem. 42, 743-752. doi: 10.1159/ 000477891

Pillai, S., Bikle, D. B., Eessalu, T. E., Aggarwal, B. B., and Elias, P. M. (1989). Binding and biological effects of tumor necrosis factor alpha on cultured human neonatal foreskin keratinocytes. J. Clin. Invest. 83, 816-821. doi: 10.1172/ jci113963

Qadir, A. S., Lee, H. L., Baek, K. H., Park, H. J., Woo, K. M., Ryoo, H. M., et al. (2011). Msx2 is required for TNF- $\alpha$-induced canonical Wnt signaling in 3T3L1 preadipocytes. Biochem. Biophys. Res. Commun. 408, 399-404. doi: 10.1016/ j.bbrc.2011.04.029

Qi, F., Song, J., Yang, H., Gao, W., Liu, N., Zhang, B., et al. (2010). Mmp23b promotes liver development and hepatocyte proliferation through the tumor necrosis factor pathway in zebrafish. Hepatology 52, 2158-2166. doi: 10.1002/ hep. 23945

Qin, Z., Fang, Z., Zhao, L., Chen, J., Li, Y., and Liu, G. (2015). High dose of TNF- $\alpha$ suppressed osteogenic differentiation of human dental pulp stem cells by activating the Wnt/ $\beta$-catenin signaling. J. Mol. Histol. 46, 409-420. doi: 10.1007/s10735-015-9630-7

Rodgers, K. R., Lin, Y., Langan, T. J., Iwakura, Y., and Chou, R. C. (2020). Innate immune functions of astrocytes are dependent upon tumor necrosis factor-alpha. Sci. Rep. 10:7047. doi: 10.1038/s41598-020-63766-2

Sadowsky, D. W., Adams, K. M., Gravett, M. G., Witkin, S. S., and Novy, M. J. (2006). Preterm labor is induced by intraamniotic infusions of interleukin$1 \beta$ and tumor necrosis factor- $\alpha$ but not by interleukin- 6 or interleukin- 8 in a nonhuman primate model. Am. J. Obstet. Gynecol. 195, 1578-1589. doi: 10.1016/j.ajog.2006.06.072

Sanders, E. J., Prasad, S., Hu, N., and Wride, M. A. (1997). Cell death in the gastrulating chick embryo: potential roles for tumor necrosis factor-alpha (TNF- $\alpha$ ). Cell Death Differ. 4, 188-199. doi: 10.1038/sj.cdd.4400235

Schreurs, R. R. C. E., Baumdick, M. E., Sagebiel, A. F., Kaufmann, M., Mokry, M., Klarenbeek, P. L., et al. (2019). Human fetal TNF- $\alpha$-cytokine-producing CD4 + effector memory T cells promote intestinal development and mediate inflammation early in life. Immunity 50, 462.e8-476.e8.

Seleme, M. C., Kosmac, K., Jonjic, S., and Britt, W. J. (2017). Tumor necrosis factor alpha-induced recruitment of inflammatory mononuclear cells leads to inflammation and altered brain development in murine cytomegalovirusinfected newborn mice. J. Virol. 91:e1983-16. doi: 10.1128/JVI.01983-16

Sharples, A. P., Polydorou, I., Hughes, D. C., Owens, D. J., Hughes, T. M., and Stewart, C. E. (2016). Skeletal muscle cells possess a 'memory' of acute early life TNF- $\alpha$ exposure: role of epigenetic adaptation. Biogerontology 17, 603-617. doi: 10.1007/s10522-015-9604-x

Sidney, L. E., Kirkham, G. R., and Buttery, L. D. (2014). Comparison of osteogenic differentiation of embryonic stem cells and primary osteoblasts revealed by responses to IL-1 $\beta$, TNF- $\alpha$, and IFN- $\gamma$. Stem Cells Dev. 23, 605-617. doi: $10.1089 / \mathrm{scd} .2013 .0336$

Singhatanadgit, W., Salih, V., and Olsen, I. (2006). Bone morphogenetic protein receptors and bone morphogenetic protein signaling are controlled by tumor necrosis factor- $\alpha$ in human bone cells. Int. J. Biochem. Cell Biol. 38, 1794-1807. doi: 10.1016/j.biocel.2006.05.005

Su, Z., Yuan, Y., Chen, J., Zhu, Y., Qiu, Y., Zhu, F., et al. (2011). Reactive astrocytes inhibit the survival and differentiation of oligodendrocyte precursor cells by secreted TNF- $\alpha$. J. Neurotrauma. 28, 1089-1100. doi: 10.1089/neu.2010.1597

Sullivan, C. B., Porter, R. M., Evans, C. H., Ritter, T., Shaw, G., Barry, F., et al. (2014). TNF- $\alpha$ and IL-1 $\beta$ influence the differentiation and migration of murine MSCs independently of the NF-кB pathway. Stem Cell Res. Ther. 5:104. doi: $10.1186 /$ scrt492

Takahashi, S., Uchimaru, K., Harigaya, K., Asano, S., and Yamashita, T. (1992). Tumor necrosis factor and interleukin-1 induce activin A gene expression in a human bone marrow stronal cell line. Biochem. Biophys. Res. Commun. 188, 310-317. doi: 10.1016/0006-291x(92)92386-c

Tang, P., Hung, M. C., and Klostergaard, J. (1996). Human pro-tumor necrosis factor is a homotrimer. Biochemistry 35, 8216-8225. doi: 10.1021/bi952182t

Tani-Ishii, N., Tsunoda, A., Teranaka, T., and Umemoto, T. (1999). Autocrine regulation of osteoclast formation and bone resorption by IL-1 alpha and TNF alpha. J. Dent. Res. 78, 1617-1623. doi: 10.1177/00220345990780100601

Tashjian, A. H., Voelkel, E. F., Lazzaro, M., Goad, D., Bosma, T., and Levine, L. (1987). Tumor necrosis factor- $\alpha$ (cachectin) stimulates bone resorption in mouse calvaria via a prostaglandin-mediated mechanism. Endocrinology 120, 2029-2036. doi: 10.1210/endo-120-5-2029

Tayman, C., Aydemir, S., Yakut, I., Serkant, U., Ciftci, A., Arslan, E., et al. (2016). TNF- $\alpha$ blockade efficiently reduced severe intestinal damage in necrotizing enterocolitis. J. Investig. Surg. 29, 209-217. doi: 10.3109/08941939.2015. 1127449

Tong, X., and Coulombe, P. A. (2006). Keratin 17 modulates hair follicle cycling in a TNF $\alpha$-dependent fashion. Genes Dev. 20, 1353-1364. doi: 10.1101/gad. 1387406

Torchinsky, A., Shepshelovich, J., Orenstein, H., Zaslavsky, Z., Savion, S., Carp, H., et al. (2003). TNF- $\alpha$ protects embryos exposed to developmental toxicants. Am. J. Reprod. Immunol. 49, 159-168. doi: 10.1034/j.1600-0897.2003.01174.x

Turcatel, G., Millette, K., Thornton, M., Leguizamon, S., Grubbs, B., Shi, W., et al. (2017). Cartilage rings contribute to the proper embryonic tracheal epithelial differentiation, metabolism, and expression of inflammatory genes. Am. J. Physiol. Lung Cell. Mol. Physiol. 312, L196-L207.

Van Der Pluijm, G., Most, W., Van Der Wee-Pals, L., De Groot, H., Papapoulos, S., and Löwik, C. (1991). Two distinct effects of recombinant human tumor necrosis factor- $\alpha$ on osteoclast development and subsequent resorption of mineralized matrix. Endocrinology 129, 1596-1604. doi: 10.1210/endo-129-31596

Wang, L., Chopp, M., Teng, H., Bolz, M., Francisco, M. Ã, Aluigi, D. M., et al. (2011). Tumor necrosis factor $\alpha$ primes cerebral endothelial cells for erythropoietin-induced angiogenesis. J. Cereb. Blood Flow Metab. 31, 640-647. doi: $10.1038 /$ jcbfm.2010.138

Wang, M., Crisostomo, P. R., Herring, C., Meldrum, K. K., and Meldrum, D. R. (2006). Human progenitor cells from bone marrow or adipose tissue produce VEGF, HGF, and IGF-I in response to TNF by a p38 MAPK-dependent mechanism. Am. J. Physiol. Regul. Integr. Comp. Physiol. 291, R880-R884. doi: 10.1152/ajpregu.00280.2006

Wang, Y., Wu, B., Farrar, E., Lui, W., Lu, P., Zhang, D., et al. (2017). Notch-TNF signalling is required for development and homeostasis of arterial valves. Eur. Heart J. 38, 675-686.

Wang, Z., He, X., and Fan, X. (2018). Postnatal administration of memantine rescues TNF- $\alpha$-induced decreased hippocampal precursor proliferation. Neurosci. Lett. 662, 173-180. doi: 10.1016/j.neulet.2017.10.022 
Witsell, A. L., and Schook, L. B. (1992). Tumor necrosis factor $\alpha$ is an autocrine growth regulator during macrophage differentiation. Proc. Natl. Acad. Sci. U.S.A. 89, 4754-4758. doi: 10.1073/pnas.89.10.4754

Wuu, Y. D., Pampfer, S., Vanderheyden, I., Lee, K. H., and De Hertogh, R. (1998). Impact of tumor necrosis factor on mouse embryonic stem cells. Biol. Reprod. 58, 1416-1424.

Xu, D. X., Chen, Y. H., Wang, H., Zhao, L., Wang, J. P., and Wei, W. (2006). Tumor necrosis factor alpha partially contributes to lipopolysaccharide- induced intrauterine fetal growth restriction and skeletal development retardation in mice. Toxicol. Lett. 163, 20-29.

Yamazaki, M., Fukushima, H., Shin, M., Katagiri, T., Doi, T., Takahashi, T., et al. (2009). Tumor necrosis factor $\alpha$ represses bone morphogenetic protein (BMP) signaling by interfering with the DNA binding of smads through the activation of NF-кB. J. Biol. Chem. 284, 35987-35995.

Yao, S., Prpic, V., Pan, F., and Wise, G. E. (2010). TNF- $\alpha$ upregulates expression of BMP-2 and BMP-3 genes in the rat dental follicle-Implications for tooth eruption. Connect. Tissue Res. 51, 59-66.

Yoshida, S., Ono, M., Shono, T., Izumi, H., Ishibashi, T., Suzuki, H., et al. (1997). Involvement of interleukin-8, vascular endothelial growth factor, and basic fibroblast growth factor in tumor necrosis factor alpha-dependent angiogenesis. Mol. Cell. Biol. 17, 4015-4023.

Yoshimatsu, Y., Kimuro, S., Pauty, J., Takagaki, K., Nomiyama, S., Inagawa, A., et al. (2020). TGF-beta and TNF-alpha cooperatively induce mesenchymal transition of lymphatic endothelial cells via activation of Activin signals. PLoS One. 15:e0232356. doi: 10.1371/journal.pone.0232356
Zhang, A., Wang, Y., Ye, Z., Xie, H., Zhou, L., and Zheng, S. (2010). Mechanism of TNF- $\alpha$-induced migration and hepatocyte growth factor production in human mesenchymal stem cells. J. Cell. Biochem. 111, 469-475.

Zou, W., Hakim, I., Tschoep, K., Endres, S., and Bar-Shavit, Z. (2001). Tumor necrosis factor- $\alpha$ mediates RANK ligand stimulation of osteoclast differentiation by an autocrine mechanism. J. Cell. Biochem. 83, 70-83.

Zúñiga-Pflücker, J. C., Jiang, D., and Lenardo, M. J. (1995). Requirement for TNF$\alpha$ and IL- $1 \alpha$ in fetal thymocyte commitment and differentiation. Science 268, 1906-1909.

Conflict of Interest: The authors declare that the research was conducted in the absence of any commercial or financial relationships that could be construed as a potential conflict of interest.

Publisher's Note: All claims expressed in this article are solely those of the authors and do not necessarily represent those of their affiliated organizations, or those of the publisher, the editors and the reviewers. Any product that may be evaluated in this article, or claim that may be made by its manufacturer, is not guaranteed or endorsed by the publisher.

Copyright (c) 2021 You, Gu, Yuan and Xu. This is an open-access article distributed under the terms of the Creative Commons Attribution License (CC BY). The use, distribution or reproduction in other forums is permitted, provided the original author(s) and the copyright owner(s) are credited and that the original publication in this journal is cited, in accordance with accepted academic practice. No use, distribution or reproduction is permitted which does not comply with these terms. 